УДК 159.922-057.875

doi: $10.15330 /$ ps.10.1.159-166

Марина Омельченко

ДВНЗ «Донбаський державний педагогічний університет», neckaa87@gmail.com

\title{
РОЗВИТОК ПРОФЕСІЙНОЇ СВІДОМОСТІ НА ЕТАПІ НАВЧАННЯ У ЗАКЛАДАХ ВИЩОЇ ОСВІТИ: СПРОБА КОНЦЕПТУАЛІЗАЦЇ̈
}

Дана стаття присвячена проблемі пошуку детермінант професійного розвитку особистості на етапі професійної підготовки. Особливу увагу авторка приділяє прочесу розвитку професійної свідомості, обтрунтовує його вирішальну роль у становленні особистості майбутнього фахівия, оскільки саме цей процес визначає формування індивідуального стилю діяльності людини, розвиток професійної творчості й прогресивних поглядів, формування інтересів, иінностей, мотивів, рефлексії. Підкреслюється актуальність проблеми структуризаиї професійної свідомості, визначення ії місия і значення в механізмі професійного розвитку особистості. Встановлено й інші фактори професійного розвитку особистості - професійноособистісні якості й професійна компетентність, обтрунтовано їхню взаємообумовленість. На основі наукового аналізу структури професійної свідомості та їі складових компонентів - когнітивного, рефлексивного, аксіологічного, мотивачійного, афективного блоків визначено відповідні напрямки розвитку професійної свідомості та їхні показники: усвідомлення професійної дійсності; становлення професійного «Я»; усвідомлене оцінювання себе як фахівия; усвідомлення професійних иінностей; визначення свідомих професійних мотивів; усвідомлене переживання професійних емочій; усвідомлене уникнення професійних стресів і вигорання. На основі виділених детермінант професійного розвитку (становлення професійноособистісних якостей і професійної компетентності фахівия), а також напрямків розвитку професійної свідомості розроблено й представлено авторську модель становлення професійної свідомості фахівия. Отримані шляхом аналітичного огляду літератури дані дозволяють перейти до наступного етапу дослідження механізмів розвитку професійної свідомості з метою розроблення відповідних ефективних тренінгових програм і оптимізації процесу професійної підготовки фахівців у закладах вищої освіти.

Ключові слова: професійна підготовка; професійна свідомість; професійний розвиток; фахівець.

Постановка наукової проблеми та її значення. На сучасному етапі розвитку суспільства професійна підготовка майбутніх фахівців зорієнтована перш за все на розвиток творчого потенціалу особистості фахівця, його здатності знаходити рішення в нестандартних ситуаціях, спілкуватися і взагалі взаємодіяти 3 людьми 3 позиції поваги й толерантності. В сучасній психології проблема становлення професійної свідомості фахівця виходить на передній план, оскільки саме цей процес детермінує формування індивідуального стилю діяльності людини, розвиток професійної творчості й прогресивних поглядів, формування інтересів, цінностей, мотивів, рефлексії та ін. Відтак актуальною стає проблема становлення професійної свідомості, визначення ії місця і значення в професійному розвитку особистості.

Аналіз останніх досліджень за проблемою. Визначена актуальність проблеми становлення професійної свідомості фахівця грунтується на результатах досліджень Р. Бернса, С. Клімова, С. Пантилеєва, К. Роджерса, С. Століна, в яких зазначено, що професійна свідомість бере початок в ході здійснення професійного вибору й, розвиваючись, стає потужним чинником і регулятором процесу професійного розвитку особистості як фахівця. Закордоном спроби вивчення особливостей і значення становлення професійної свідомості знаходимо в працях сучасних психологів D. L. Blustein, J. S. Eccles, L. S. Gottfredson, S. F. Hamilton, R. W. Lent, M. L. Savickas, D. E. P. Schultheiss, D. E. Super, S. C. Whiston та ін., в яких здійснення професійного вибору пов'язується, перш за все, з самосвідомістю індивіда, його ставленням до певної професії, професійною позицією й самовизначенням перспектив професійного розвитку. Проблемам розвитку професійної свідомості у процесі підготовки до професії присвячено чимало робіт вітчизняних і зарубіжних вчених, серед яких О. Еннс, О. Кокун, Н. Рукавішнікова, О. Семенова, В. Швецова, Н. Шевченко, T. Zhou, J. Chen, L. Luo та ін.. Незважаючи на численність окреслених наукових здобутків, до сих пір немає чіткого визначення напрямків та місця категорії розвитку професійної свідомості фахівця в системі професійного розвитку особистості. 
Формулювання мети і завдань статті. Метою цієї статті є розроблення моделі професійного розвитку особистості на основі аналітичного огляду психологічної літератури; завданнями - визначення напрямків і місця професійної свідомості в системі професійного розвитку особистості.

Виклад основного матеріалу й обгрунтування отриманих результатів дослідження. Проблема визначення структури і компонентів професійної свідомості особистості на етапі професійної підготовки приваблювала багатьох вчених - як психологів, так і педагогів. Розглянемо деякі з цих здобутків. О. Семенова професійну свідомість студентів розглядала в трьох аспектах: особливості розуміння фахівцем професійної дійсності, визначення свого місця в ньому; взаємини з іншими суб' єктами професійної діяльності; конкретні професійні дії, які забезпечують регуляцію поведінки й діяльності в межах професійних норм. Результати формувального експерименту, який здійснила вчена, засвідчили, що впровадження тренінгової програми, спрямованої на підвищення якісних показників за кожним визначеним компонентом, дає високі результати й дозволяє оптимізувати процеси формування уявлень про професію, регуляцію професійних взаємин, підвищення якості професійних дій [5].

Більш поширену структуризацію професійної свідомості студентів, яка включала шість компонентів, давав Т. Фам: усвідомлення професійної моралі, яка має бути включена в будь-яку професію; здатність обрати засоби й шляхи для виконання діяльності відповідно до норм суспільства; усвідомлення себе суб'єктом професійної діяльності: усвідомлення відповідальності, цілей, засобів, умов виконання діяльності, результату; формування індивідуального стилю діяльності; усвідомлення професійно важливих якостей; усвідомлення й оцінка професійних взаємин; усвідомлення власного розвитку в часовому вимірі: усвідомлення зв'язку між минулим, теперішнім і майбутнім [8]. Слід припустити, що компонент усвідомлення професійної моралі та здатність знаходити шляхи ії підвищення можна об'єднати в єдиний компонент і розглядати як моральний аспект професійної діяльності.

Дослідницька діяльність вітчизняної вченої Н. Шевченко спрямована на визначення динаміки індивідуальних значень професійного простору, що виявляє процес становлення образу майбутньої професії. В процесі психологічного дослідження було встановлено: невідповідність предметно-дисциплінарної побудови навчального плану належній орієнтації навчання на кінцеві результати в практичній діяльності студента; гальмування власної активності студентів старших курсів, що пояснюється переживаннями внутрішнього конфлікту («смисловий конфлікт»). Підводячи підсумки, Н. Шевченко наголошувала на тому, що кризи й протиріччя, які відбуваються впродовж усього періоду професійної підготовки, потребують пошуку й осмислення нових підходів до побудови змісту професійної підготовки, нових активних методів навчання, які потребують від суб'єктів аналізу й інтерпретації дій, висловлювань та вчинків [10].

Аналогічне дослідження, але зі студентами-педагогами, було проведено Н. Рукавишніковою. За виявленими результатами динаміки розвитку професійної свідомості було встановлено, що в процесі перших трьох років професійної підготовки у більшості педагогів втрачається особистісний смисл професійного навчання, що проявляється в незадоволеності вибором фаху навчання, бажанні перервати професійний шлях. Вчена знаходила такі пояснення даному феномену, як недостатність знань специфіки професії та відсутність належної мотивації. Стійке позитивне ставлення до себе як до суб'єкта педагогічної діяльності, на думку Н. Рукавишнікової, виступало критерієм завершеності професійного самовизначення й показником наявності особистісного смислу [4].

Усвідомлення педагогами своєї професійної ролі досліджували також зарубіжні психологи T. Zhou, J. Chen, L. Luo. Вчені зазначали, що високий показник усвідомлення професійної ролі позитивно впливає на якість педагогічної діяльності, свідчить про ініціативність у питаннях професійного розвитку й саморозвитку, являє собою внутрішню 
мотивацію; водночас емпіричні дані показали, що надмірні навчальні навантаження не дозволяють майбутньому фахівцю повною мірою усвідомити рольові норми [11].

Здійснивши дослідження професійної спрямованості студентів-психологів, В. Сич зауважив, що в студентів першого курсу фактично відсутнє широке бачення світу, не сформувалася система цінностей, характерна для даної професії, що в підсумку й визначає невираженість у них професійно значущих якостей, їхню неефективну реалізацію в процесі професійної діяльності (труднощі адаптаційного періоду) [6]. На підтвердження даної проблеми можна навести тривожні показники, виявлені в ході емпіричного дослідження процесу становлення професіонала О. Спиридоновою: 40\% людей змінюють професію протягом двох років після закінчення ЗВО; 80\% населення працює не за фахом; 20\% педагогів сільських шкіл не мають педагогічної освіти чи знаходяться на етапі ії здобуття; у міських школах відзначається постійна нестача кваліфікованих кадрів [7]. Разом із цим В. Сич зазначав, що всі ці проблеми слід вирішувати під час навчання в ході психологічних консультацій з питань професійної орієнтації, особистісного самовизначення, тренінгів, спрямованих на розвиток професійно важливих якостей, а також тестування й анкетування студентів перед вибором майбутньої діяльності [6].

Досліджуючи психологію професійного становлення різних груп фахівців, О. Кокун наполягав на тому, що внутрішні конфлікти й кризи майбутніх фахівців, викликані протиріччями в формуванні окремих компонентів свідомості, потребують здійснення психопрофілактики - усунення зовнішніх і внутрішніх факторів, які шкідливо позначаються на професійній свідомості студентів [2].

Цікавими є висновки І. Хом’юк, яка зазначала, що серед шляхів формування професійної спрямованості виокремлюються: роз'яснення соціальної значущості обраної спеціальності; переконання студентів у можливості оволодіти професією. Вчена підкреслювала, що становлення особистості студента як майбутнього фахівця супроводжується «професіоналізацією» психологічних процесів і станів, розвитком професійної спрямованості й самостійності, загальним соціальним і духовним «дозріванням» студента [9]. При цьому, аналізуючи результати дослідження професійної спрямованості студентів-психологів, Н. Іванцева наполягала на тому, що феномен професійної спрямованості студентів проявляється як у номінативних показниках їхньої мотиваційної сфери, так і в розвитку професійно важливих якостей і здібностей, у функціонуванні ціннісно-смислової сфери особистості [1].

У контексті зважання майже всіх вчених на провідну роль вузу в формуванні й розвитку професійної спрямованості фахівця, Н. Нестерова акцентувала увагу на тому, що вступ до вузу не гарантує високого рівня задоволеності професією, а основна праця покладається на викладацький склад, який мав би цілеспрямовано формувати професійну спрямованість студентів, особливо це стосується першого й другого курсів [3].

Здійснений аналітичний огляд підтверджує, що розвиток професійної свідомості багато в чому визначає хід професійного розвитку майбутніх фахівців. Виходячи з модифікованої нами структури професійної свідомості особистості, вектори ії розвитку визначаємо відповідно до окреслених структурних блоків: когнітивний, рефлексійний, аксіологічний, мотиваційний, афективний. Окрім цього, як показують результати психологічних досліджень, у ході професійної підготовки будуть відбуватися суттєві зміни в структурі професійної свідомості фахівця, обумовлені специфікою професії, формою навчання, особистісними якостями. Разом із цим слід зазначити, що професійний розвиток фахівця обумовлюється не лише становленням його професійної свідомості, але й, як підтверджено в дослідженнях О. Бодальова, А. Деркача, Є. Климова, А. Маркової, Л. Мітіної та ін., такими факторами, як розвиток професійно-особистісних якостей і формування професійної компетентності. Авторську модель професійного розвитку в ході професійної підготовки фахівця представлено на рисунку 1.

На рисунку 1 видно, що на професійний розвиток студента впливають три основні чинники: розвиток професійної свідомості, розвиток професійної компетентності, розви- 
ток професійних якостей. В даному контексті вектори розвитку професійної свідомості визначаються змістом ії структурних блоків: когнітивного, рефлексивного, аксіологічного, мотиваційного, афективного.

3 огляду на наукові здобутки Б. Ельконіна, А. Маркової та ін. когнітивний вектор розвитку передбачає, перш за все, набуття студентами професійних знань, які характеризують особливості конкретної професійної діяльності та необхідні для успішної ії реалізації. Знання можуть виступати у вигляді професійних уявлень (образів) і понять, які $\epsilon$ абстрактним і узагальненим відображенням дійсності. Саме когнітивний вектор розвитку професійної свідомості забезпечує інтеграцію професійних знань, самовдосконалення, можливість прояву креативності, здатність аналізувати професійну ситуацію, здійснювати рефлексію, критично й гнучко мислити.

Поряд із когнітивним вектором розвитку виділяємо рефлексивний, який, за результатами досліджень О. Бодальова, Д. Ельконіна, С. Рубінштейна та ін., передбачає формування в майбутнього фахівця професійної Я-концепції та професійної самооцінки. Відтак однією з обов'язкових умов професійного розвитку є формування у студента уявлень про себе як майбутнього професіонала, а також уявлення про свої реальні можливості, ті шляхи і засоби, які зможуть максимально наблизити його до професійного ідеалу. Не менш важливим елементом у структурі рефлексивного вектору розвитку професійної свідомості $є$ професійна самооцінка, яка має виражатися в адекватному оцінюванні власних професійних досягнень, рівня компетентності й стилю діяльності. При цьому професійна самооцінка й професійна Я-концепція повинні узгоджуватися між собою, оскільки для того, щоб визначити «професійний ідеал» і «професійну реальність», слід володіти здатністю адекватно оцінювати себе та інших.

Виходячи з результатів психологічних досліджень А. Капської, Г. Лактіонової, С. Харченко та ін., аксіологічний вектор професійного розвитку студентів визначаємо як формування у них системи професійно-ціннісних орієнтацій, що багато в чому залежить від здатності до рефлексї. Професійно-ціннісні орієнтації мають грунтуватися на моральному аспекті професійної діяльності: професійній відповідальності, повазі до колег і до себе як перспективного кваліфікованого фахівця, який старанно і професійно виконує свої обов'язки. 


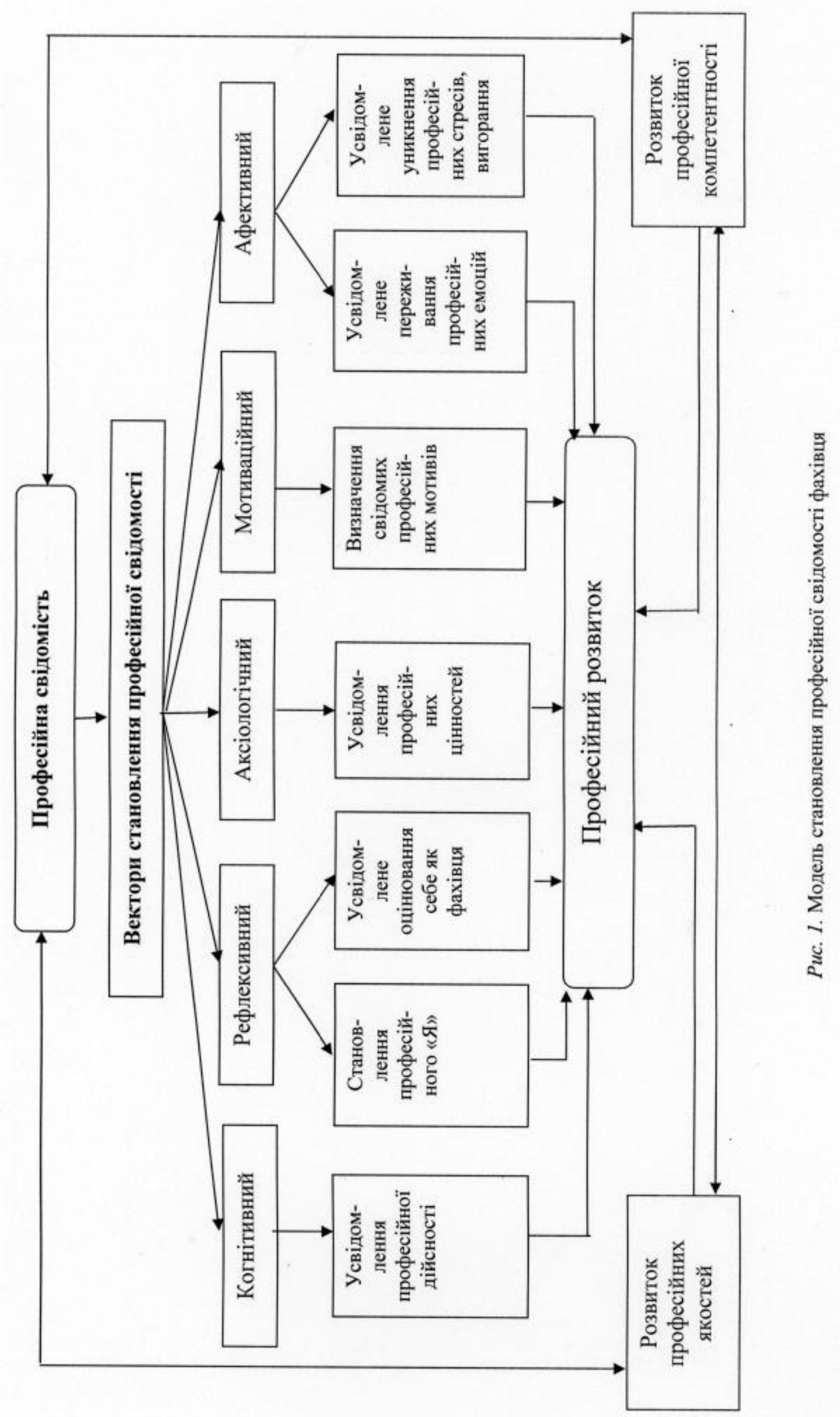


Зміст мотиваційного вектору розвитку професійної свідомості - формування стійкої професійної мотивації - було визначено з огляду на результати наукових здобутків С. Ільїна, В. Ковальова, О. Леонтьєва, П. Якобсона, А. Маслоу. Численні дослідження демонструють потужну роль професійної мотивації в професійному зростанні фахівців і формуванні конкурентоспроможної професійної діяльності на світовому ринку праці. Саме тому зазначені вчені наполягали на необхідності формувати стійку мотивацію на етапі професійної підготовки шляхом професійної практики й розкриття можливостей позитивного використання професійного досвіду.

Роль афективного фактору в професійному розвитку майбутнього фахівця підтверджено дослідженнями А. Карпова, І. Кона, О. Прохорова, Т. Яблонської та ін., результати яких дозволяють зазначити, що професійна підготовка студентів має обов'язково включати розвиток адекватних професійних емоцій i почуттів i, що важливе, профілактику стресів та емоційного вигорання. У змістовому наповненні афективного вектору ці завдання реалізуються через формування уявлень про професійні емоції та емоційні стани, здатність усвідомлювати й керувати власними емоціями, розуміти емоції інших, проектувати стосунки з іншими людьми.

3 огляду на проаналізовані за даною проблематикою дослідження, не можна вважати, що професійний розвиток майбутнього фахівця обмежується лише процесом розвитку його професійної свідомості. Потужними факторами виступають також розвиток професійних якостей і формування професійної компетентності студента. При цьому, як видно на рисунку 1, всі три зазначені фактори впливу є взаємозумовленими. Професійна свідомість фахівця, безумовно, впливає на хід розвитку його професійних якостей i формування компетентності. 3 іншого боку, характер становлення блоків професійної свідомості визначається своєрідністю професійних якостей фахівця та рівнем його професійної компетентності.

Висновки та перспективи подальших досліджень. Визначення й обгрунтування детермінант професійного розвитку особистості дозволило розробити відповідну модель, визначити в ній місце професійної свідомості та вектори їі становлення: когнітивний, рефлексивний, аксіологічний, мотиваційний, афективний. Отримані дані дозволяють перейти до наступного етапу - дослідження механізмів розвитку професійної свідомості 3 метою розроблення відповідних ефективних тренінгових програм і оптимізації процесу професійної підготовки фахівців у закладах вищої освіти.

1. Іванцова, Н. Б. (2007). Психологічні особливості розвитку професійної спрямованості особистості. Проблеми загальної. та педагогічної. психологї: зб. наук. пр. Ін-ту психології ім. Г. С. Костюка АПН України, 9, 2, 119-124.

2. Кокун, О. М. (2012). Психологія професійного становлення сучасного фахівия: монографія. Київ: ДП «Інформ.-аналіт. агенство".

3. Нестерова, Н. Б. (2014). Профессиональная направленность студентов технического вуза. Экономика и экологический менеджмент, 2, 54-62.

4. Рукавишникова, Н. Г. (2003). Профессиональное самосознание студентов педагогического вуза. Ярославский педагогический вестник, 11, 49-55.

5. Семенова, Е. А. (2008). Возможности развития профессионального самосознания студентов в образовательном пространстве технического университета Высшее образование сегодня, 7, 23-25.

6. Сич, В. М. (2005). Соціально-психологічні особливості мотивацї професійного вдосконалення спеціалістів відділу освіти (Дис. канд. психол. наук). Інститу психології АПН України, Київ.

7. Спиридонова, Е. А. (2015). Формирование профессиональной направленности личности студента как ведущий фактор профессионализма в педагогической деятельности. Психологическое сопровождение безопасности образовательной среды школь в условиях стандарта внедрения новых образовательных ы профессиональных стандартов. Москва: МГППУ, 38-42.

8. Фам, Т. Н. (1989). Развитие профессионального самосознания студентов технических вузов. (Автореф. дис. канд. психол. наук). Москва.

9. Хом'юк, І. В. (2008). Шляхи формування професійної спрямованості студента. Сучасні інформаційні технології та інноваційні методики навчання в підготовичі фахівціів: Збірник наукових праць, 18, $359-364$. 
10. Шевченко, Н. Ф. (2005). Структурно-функціональна модель професійної свідомості практичного психолога. Вісник Харківського начіонального педагогічного університету ім. Г. С. Сковороди. Психологія, $15,1,185-195$.

11. Zhou, T., Chen, J., Luo, L. (2013). The Relationship between Consciousness of Professional Role and Work Autonomy of Rural Teachers from Sichuan Province. Psychology, 4, 11, 864-869.

\section{REFERENCES}

1. Ivantsova, N. B. (2007). Metodolohiia doslidzhennia profesiinoi spriamovanosti studentiv-psykholohiv [Methodology of research of students-psychologists' professional orientation]. Problemy zahal'noyi ta pedahohichnoyi. psykholohiyi [Problems of general and pedagogical], 9, 2, 119-124. (ukr).

2. Kokun, O. M. (2012). Psykholohiia profesiinoho stanovlennia suchasnoho fakhivtsia [Psychology of the modern specialist's professional formation]: monohrafiia. K.: DP «Inform.-analit. ahenstvo». (ukr).

3. Nesterova, N. B. (2014). Professional'naja napravlennost' studentov tehnicheskogo vuza [Professional orientation of students of the technical university]. Jekonomika i jekologicheskij menedzhment [Economics and environmental management], 2, 54-62. (rus).

4. Rukavishnikova, N. G. (2003). Professional'noe samosoznanie studentov pedagogicheskogo vuza [Professional identity of students of the pedagogical university]. Jaroslavskij pedagogicheskij vestnik [Yaroslavl Pedagogical Bulletin], 11, 49-55. (rus).

5. Semenova, E. A. (2008). Vozmozhnosti razvitija professional'nogo samosoznanija studentov v obrazovatel'nom prostranstve tehnicheskogo universiteta [Opportunities for the development of students' professional self-awareness in the educational space of the technical university]. Vysshee obrazovanie segodnja [Higher education today], 23-25. (rus).

6. Sych, V. M. Sotsialno-psykholohichni osoblyvosti motyvatsii profesiinoho vdoskonalennia spetsialistiv viddilu osvity [Social and psychological peculiarities of the motivation of professional improvement at specialists of education department] (Dys. kand. psykhol. nauk). Kyiv. (ukr).

7. Spiridonova, E. A. (2015). Formirovanie professional'noj napravlennosti lichnosti studenta kak vedushhij faktor professionalizma v pedagogicheskoj dejatel'nosti [The formation of professional orientation of the student's personality as a leading factor in professionalism in pedagogical activity]. Psihologicheskoe soprovozhdenie bezopasnosti obrazovatel'noj sredy shkoly $v$ uslovijah standarta vnedrenija novyh obrazovatel'nyh y professional'nyh standartov [Psychological support of the safety of the educational environment of the school in the context of the standard for the implementation of new educational and professional standards]: Sbornik nauchnyh statej. Moskov: MGPPU, 38-42. (rus).

8. Fam, T. N. (1989). Razvitie professional'nogo samosoznanija studentov tehnicheskih vuzov [The development of professional identity at the students of technical universities] (Avtoref. dis. kand. psihol. nauk). Moskov. (rus).

9. Khomiuk, I. V. (2008). Shliakhy formuvannia profesiinoi spriamovanosti studenta [Ways of forming a student's professional orientation]. Suchasni informatsiini tekhnolohii ta innovatsiini metodyky navchannia $v$ pidhotovtsi fakhivtsiv [Modern information technologies and innovative teaching methods in the training of specialists], 18, 359-364. (ukr).

10. Shevchenko, N. F. (2005). Strukturno-funktsionalna model profesiinoi svidomosti praktychnoho psykholoha [Structural and functional model of the practical psychologist's professional consciousness]. Visnyk Kharkivskoho natsionalnoho pedahohichnoho universytetu im. H. S. Skovorody. Psykholohiia [Bulletin of Kharkiv National Pedagogical University G. S. Skovorody. Psychology], 15, 1, 185-195. (ukr).

11. Zhou, T., Chen, J., Luo, L. (2013). The Relationship between Consciousness of Professional Role and Work Autonomy of Rural Teachers from Sichuan Province. Psychology, 4, 11, 864-869.

\section{Maryna Omelchenko \\ PROFESSIONAL AWARENESS DEVELOPMENT AT LEARNING STAGE IN HIGHER EDUCATION INSTITUTIONS: TRYING CONCEPTUALIZATION}

This scientific article is devoted to search the determinants of individual's professional development during training phase. The author focuses on development of professional consciousness, substantiate its decisive role in formative years of future professionals, since the editing process determines the formation of human activity's individual style, the development of professional creativity and progressive views, the formation of interests, values, motives, reflection. The article stressed problem of how to generate towards of professional consciousness, to determine its places and meanings in the mechanism of personality's professional development. It had also established other factors of personality's professional development - professional and personal qualities and professional competence, its interdependence is substantiated. Through the scientific analysis of structure of professional consciousness and its constituent components - cognitive, reflective, axiological, motivational, affective blocks, the corresponding directions of professional consciousness development and their indicators are defined: awareness of professional reality; becoming a professional «I»; conscious evaluation of yourself as a specialist; awareness of professional values; determination of conscious professional motives; conscious experience 
of professional emotions; conscious avoidance of professional stress and burnout. Working with these determinants of professional development (development of professional-personal qualities and professional competence of a specialist) and the development of professional consciousness, was developed and presented an author's model of professional consciousness development. The author submits that figures provided by review of the literature enable to move on to the next stage - research into the professional consciousness' development with a view to developing appropriate effective training programs and optimizing the training process at the university.

Keywords: professional training; professional consciousness; professional development; professional. 